\title{
Water Resources of Bill
}

Williams River Valley

\section{Near Alamo, Arizona}

GEOLOGICAL SURVEY WATER-SUPPLY PAPER 1360-D

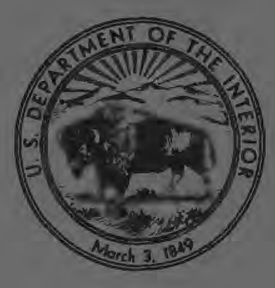




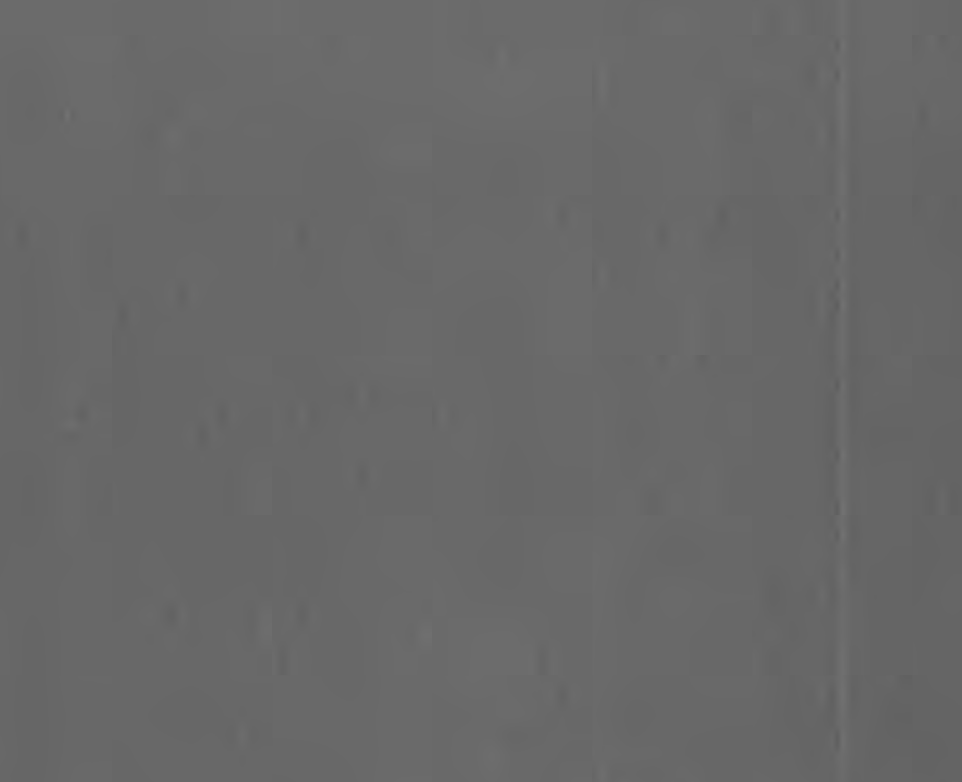

1) 18

II. 
DEC 101956

\section{Water Resources of Bill}

\section{Williams River Valley}

\section{Near Alamo, Arizona}

By H. N. WOLCOTT, H. E. SKIBITZKE, and L. C. HALPENNY

CONTRIBUTIONS TO THE HYDROLOGY OF THE UNITED STATES

GEOLOGICAL SURVEY WATER-SUPPLY PAPER 1360-D

An investigation of the availability

of water in the area of the

Artillery Mountains

manganese deposits

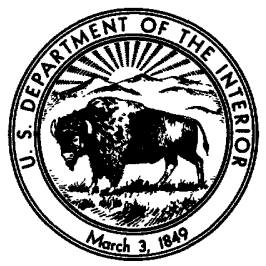




\section{UNITED STATES DEPARTMENT OF THE INTERIOR}

Fred A. Seaton, Secretary

\section{GEOLOGIGAL SURVEY}

Thomas B. Nolan, Director 


\section{CONTENTS}

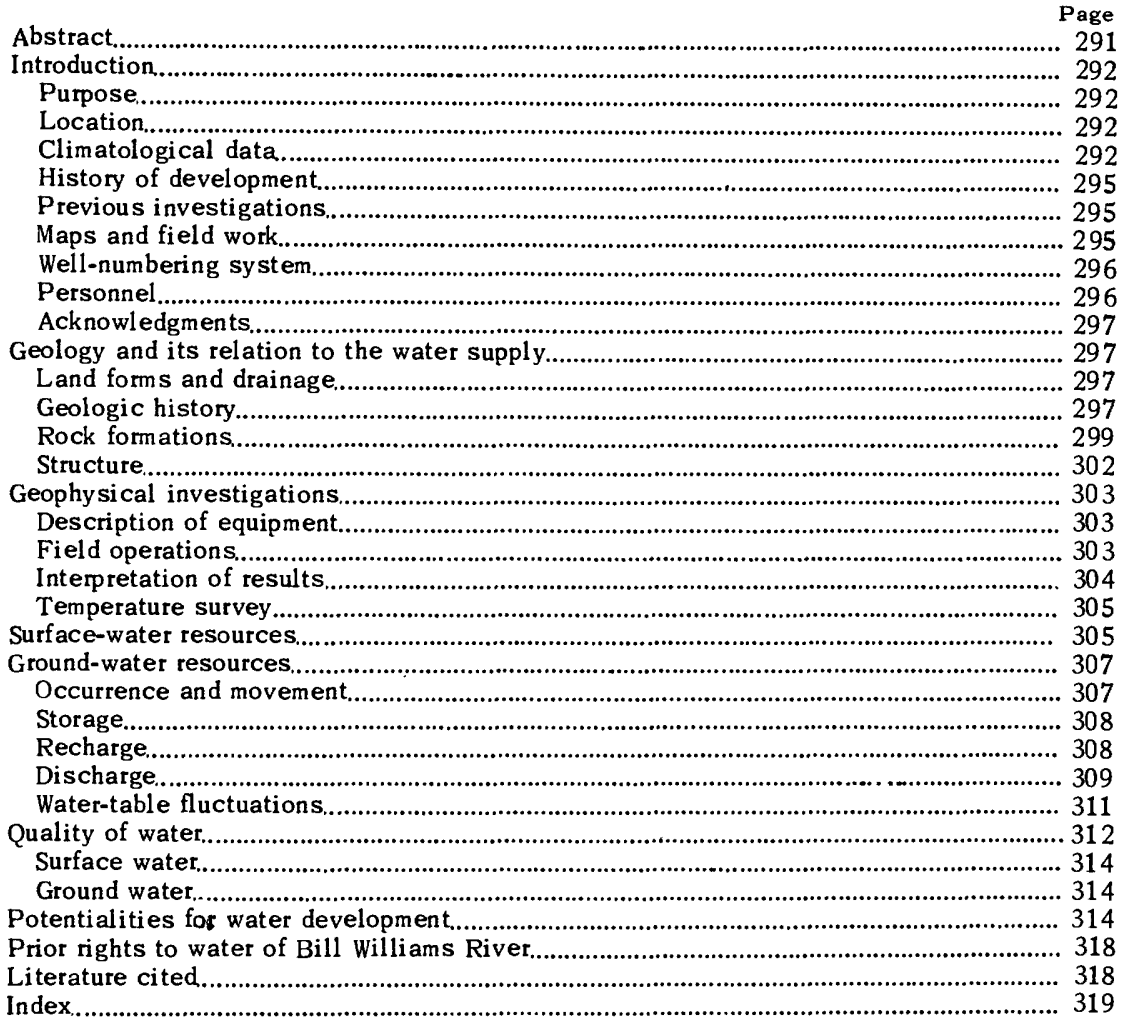

\section{ILLUSTRATIONS}

Plate 21. Map of Bill Williams River valley near Alamo, showing Recent alluvium and locations of wells, springs, and electrical-resistivity probe sites.

In pocket

Page

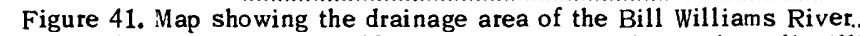
293

42. Precipitation in 1946 at stations in and near the Bill Williams River and drainage basin, and discharge of Bill Williams River near Alamo

43. Diagrammatic section across Bill Williams River near Alamo.

44. Cross sections showing probable thickness of Recent alluvium along Bill Williams River near Alamo

45. Three-year progressive average of precipitation at Salome, Ariz., for the period 1914-53. 
TABLES

Table 1. Formations in the Artillery Mountains manganese area

2. Momentary maximum, minimum, and mean discharge of Santa Maria and Bill Williams Rivers for water years 1943-52.

3. Records of wells and springs in Bill Williams River valley near Alamo, 1951.

4. Analyses of water from wells, sp rings, and surface streams, Bill Williams River valley.

5. Percent of time in which flow equaled or exceeded indicated discharge, Bill Williams River near Alamo, 1942-52 


\title{
CONTRIBUTIONS TO THE HYDROLOGY OF THE UNITED STATES
}

\section{WATER RESOURCES OF BILL WILLIAMS RIVER VALLEY NEAR ALAMO, ARIZONA}

\author{
By H. N. Wolcott, H. E. Skibitzke, and L. C. Halpenny
}

ABSTRACT

An investigation of the water tesources of the Bill Williams River valley near Artillery Peak and Alamo, Ariz., was made during the spring and summer of 1951 to determine the availability of water for a manganese mine in the Artillery Mountains and a proposed mill near Alamo. Geologic, hydrologic, and geophysical methods were used.

In the area studied, the Bill Williams River occupies a basin formed by post-Tertiary faulting. Owing to the comparatively recent formation of this structural trough, the river has not widened its valley appreciably; and it is apparent that side erosion did not advance extensively in the Tertiary sedimentary rocks that underlie most of the alluvial flood plain at shallow depths. The Tertiary sedimentary rocks are cemented and relatively impermeable, and therefore are not an important source of ground water. Only the unconsolidated sand and gravel of Recent age is capable of storing easily recoverable ground water, but its volume is much less than is suggested by the wide flood plain. No other important sources of ground water were found except at a considerable distance from the Alamo area.

On the basis of all data obtained, the volume of Recent alluvium along the Bill Williams River in the 6-mile reach between the confluence of the Big Sandy and Santa Maria Rivers and the gaging station near Alamo was estimated to be about 100,000 acre-feet. The quantity of ground water stored in this alluvium probably is between 10,000 and 15,000 acre-feet, but it would not be possible to withdraw the entire amount. The water in the river and in the ground-water reservoir contains moderate amounts of dissolved mineral matter, and is hard.

Recharge, derived principally from flow in the river and from direct rainfall upon the flood plain, was found to be more than sufficient to balance the ground-water discharge; the excess moves out of the area as surface flow. The total annual discharge from the area, including surface flow, underflow, evapotranspiration, and pumping, is far more than the estimated average of $7 \frac{1}{2} \mathrm{cfs}$ required for possible future mining, milling, and domestic use. However, during a period of several months in almost every year, the combined discharge amounts to considerably less than the estimated requirements. During this period withdrawals from ground-water storage would have to be made.

To provide a constant water supply of $7 \frac{1}{2} \mathrm{cfs}$ throughout periods of drought, three alternatives are suggested: (1) A subsurface dam and infiltration gallery near the Alamo gaging station, supplemented by a system of wells along the flood plain near Alamo; (2) a dam in the box canyon downstream from the Alamo gage, to provide a surface-water reservoir; and (3) the development of a supplemental ground-water supply near Planet, about 25 miles downstream from Alamo. 


\section{INTRODUCTION}

PURPOSE

Investigation of the manganese deposits in the Artillery Mountains, Mohave County, Ariz., was begun by the owners of the deposits in 1929. Since that time, further studies of the area have been made, both by the U. S. Bureau of Mines (Dean, 1934a and 1934b) and the U. S. Geological Survey (Lasky and Webber, 1949), and the deposits have been proved to be among the largest in the United States. Although the tonnage is enormous, the ores are too low in manganese content to be of industrial value without beneficiation. Regardless of what process may be developed for treatment of the ores, a large supply of water will be necessary, both for milling purposes and for domestic use. It is estimated that about $7 \frac{1}{2}$ cfs of water would be needed to supply the mine, the mill, and the necessary community of about 1,500 people. Inasmuch as previous investigations were directed primarily toward an evaluation of the mineral deposits, little was known about the availability of water. For that reason, an investigation and evaluation of the water resources was undertaken in 1951. The results of the investigation are presented in this report.

\section{LOCATION}

The Bill Williams River, a perennial interrupted stream, begins at the junction of the Big Sandy and Santa Maria Rivers (fig. 41), and forms the boundary between Mohave and Yuma Counties, Ariz. The river follows the southeast boundary of the area in which the principal manganese deposits occur, and it is the only important source of water in the vicinity.

The settlement of Alamo, about 5 miles downstream from the junction of the Big Sandy and Santa Maria Rivers, is inhabited by less than a dozen people. Alamo served as a working headquarters during the several investigations of the Artillery Mountain manganese deposits and the contiguous area. It is reached by fair graded roads from Congress Junction, about 46 miles east, or from Wenden, about 42 miles south. It is also reached by road from Yucca, 63 miles north.

\section{CLIMATOLOGICAL DATA}

There is no weather station at Alamo, but climatological data are available for Salome, about 45 miles south. Climatic conditions in the two areas are comparable. Records of the U. S. 

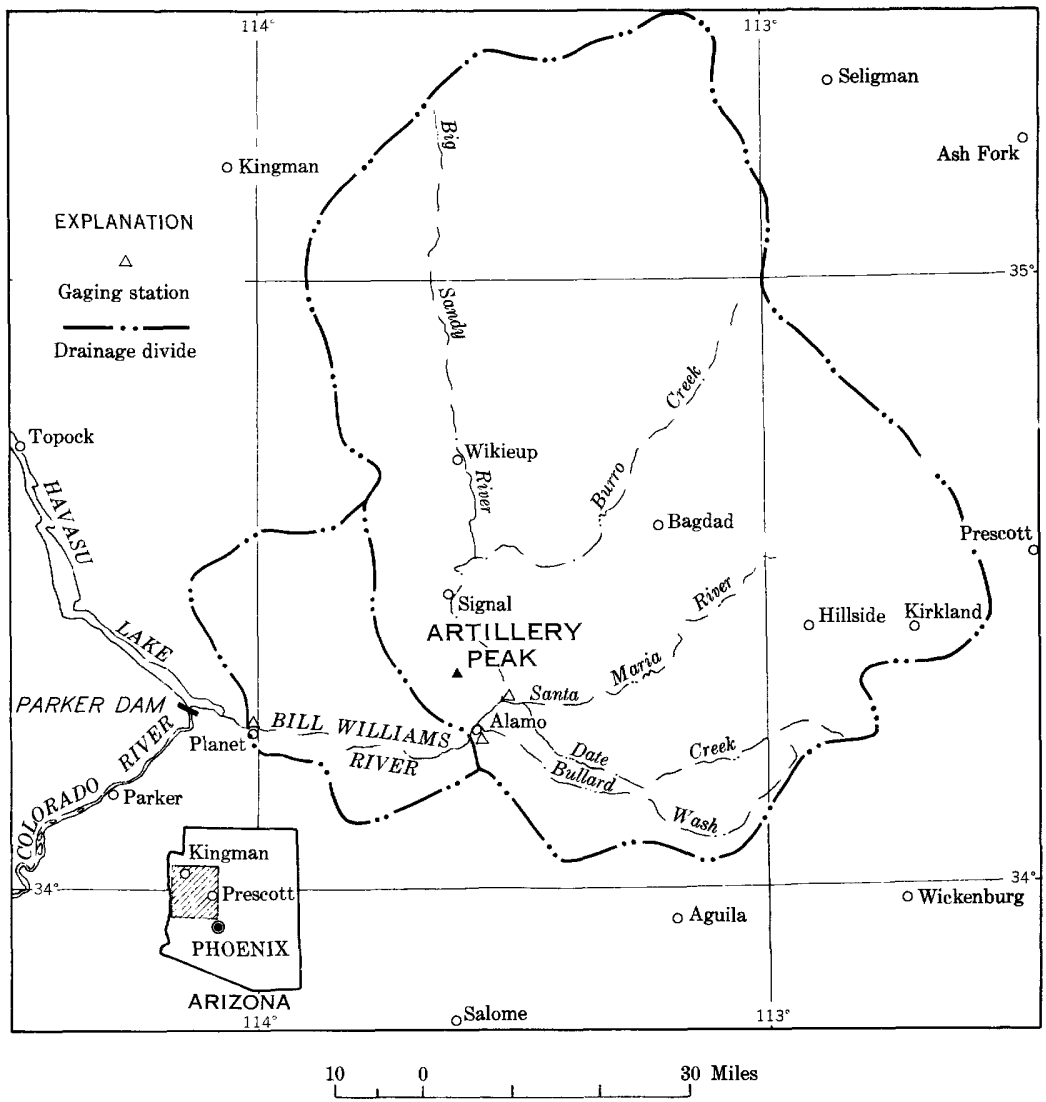

Figure 41. - Map showing the drainage area of the Bill Williams River and the portion of the drainage area above Alamo.

Weather Bureau show that the average annual precipitation at Salome for a 41 -year period ending in 1950 was 8.48 inches. During the same period the mean annual temperature was $66.9^{\circ} \mathrm{F}$, and the range was from $20^{\circ} \mathrm{F}$ in the winter to $120^{\circ} \mathrm{F}$ in the summer.

A graph (fig. 42) shows precipitation at several localities in the region (fig. 41). At Alamo, precipitation occurs almost always as rainfall, which is heaviest during the months of July and August. Winter storms are generally of moderate intensity and may continue for many days; summer storms are of ten violent and usually last but a short time.

The drainage basin of the Bill Williams River includes areas where the average annual precipitation is as much as 25 inches and where individual storms may result in extremely heavy runoff. Furthermore, the drainage area above the gaging station at 


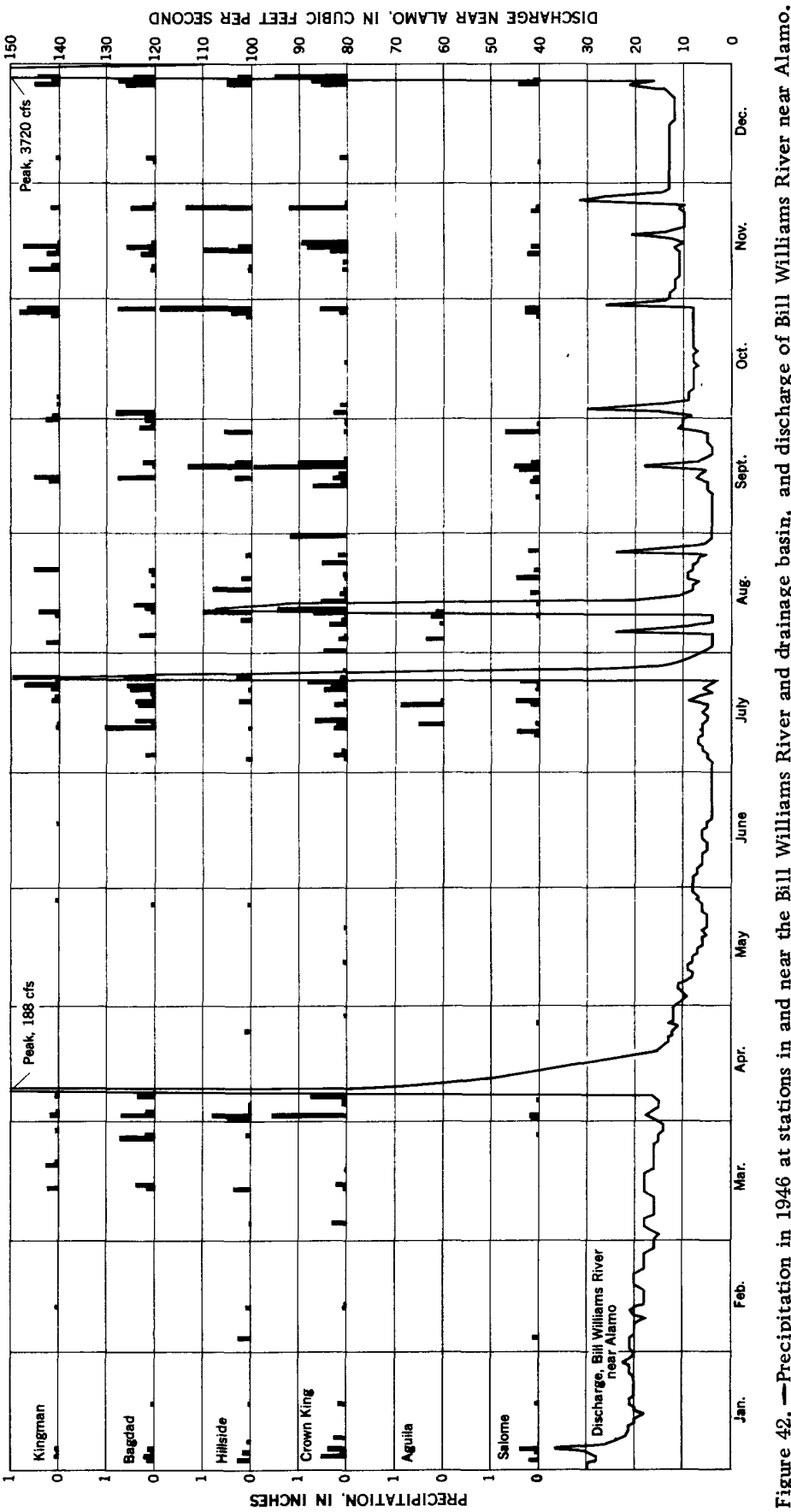


Alamo occupies 4,700 square miles and may receive heavy downpours in several places simultaneously. These conditions are responsible for occasional high floods at Alamo.

\section{HISTORY OF DEVELOPMENT}

The history of Alamo and the Artillery Peak area is related primarily todevelopment of the manganese deposits (Lasky and Webber, 1949, p. 3-6). Mining and milling, stock raising, and farming have been the chief activities, and all have been conducted on a small scale. Lack of feed has limited stock raising, and the small sizes of the flood plains along the river have limited farming. For many years water for farming and for camp and mine use was obtained from the river or from shallow dug wells near or in the river channel. Within recent years, however, a few wells of larger yield have been drilled. There was no demand for development of a large water supply before consideration of a manganese mill at Alamo, because only a small number of people live in the area and their water needs have not been great.

\section{PREVIOUS INVESTIGATIONS}

The ground-water resources of the area were briefly studied during a regional reconnaissance by Lee (1908). A gaging station has been maintained at Alamo since 1939 by the U. S. Geological Survey. Lasky and Webber (1949) presented a detailed description of the geology and mineral resources of the area and summarized workdone by previous investigators. Since the field work by Lasky and Webber, extensive mine-development studies have been made by the U. S. Bureau of Mines.

\section{MAPS AND FIELD WORK}

The geologic phase of the investigation was greatly facilitated by the use of Lasky's map Lasky and Webber, 1949, pl. 1) of the area and by contact prints of aerial photographs made by the U. S. Air Force. Topographic maps of the Bill Williams River channel and adjacent hills were used in connection with a seepage investigation conducted between Alamo and the abandoned surface-water gaging station at Planet.

Most of the field work was done between March 26 and June 1, 1951. During this period geologic and geophysical studies were made, hydrologic tests were conducted, and a seepage investigation was made along about 28 miles of the Bill Williams River 
channel downstream from Alamo. Sand points (screened, pointed sections of pipe) were driven to serve as observation wells in the channel and on the flood plain between Alamo and the confluence of the Big Sandy and Santa Maria Rivers. Three shallow wells were bored and equipped with continuous recorders to obtain data for estimating the quantity of water used by phreatophytes.

\section{WELL-NUMBERING SYSTEM}

In this report the well-numbering system is based upon the di$v$ ision of land areas into successively smaller quadrants, and locations are to the nearest 10 acres. The intersection of the Gila and Salt River Base and Meridian was taken as a central point, and the state divided into quadrants $A, B, C$, and D, progressing counterclockwise from the northeast, or $A$, quadrant. The first figure following the quadrant letter signifies the township, the second figure the range. The quadrant letter and township and range figures are enclosed by parentheses. Section numbers follow the parentheses. Each section is again divided into lettered 160-acre quadrants, but for these quadrants lowercase letters are used. Further subdivision into 40 -acre plots and finally into 10 -acre plots is indicated by the addition of two more lowercase letters. Thus, by this system, a well legally described as being in the NW $\frac{1}{4} \mathrm{NW} \frac{1}{4} \mathrm{NE} \frac{1}{4}$ sec. $16, \mathrm{~T} .11 \mathrm{~N}$., R. $12 \mathrm{~W}$., would be designated as $(\mathrm{B}-11-12) 16 \mathrm{abb}$.

\section{PERSONNEL}

The ground-water phase of the investigation was under the general direction of A. N. Sayre, chief, Ground Water Branch. Field work was done under the supervision of S. F. Turner, former district engineer, by J. M. Cahill, G. E. Hazen, P. W. Johnson, D. G. Mẹtzger, J. P. Mooseau, A. E. Robinson, H. E. Skibitzke, W. H. Wilson, H. N. Wolcott, and C. B. Yost, Jr. The report was prepared under the supervision of L. C. Halpenny, district engineer. The surface-water phase of the investigation was under the general direction of J. V. B. Wells, chief, Surface Water Branch. Field work on this phase of the project was done under the supervision of J. H. Gardiner, district engineer, by Angelo Dalcerro, C. T. Jenkins, Denver Kimberlin, and Van Lemons. The analyses of water samples were made and the quality-ofwate $r$ part of this report was reviewed under the direct supervision of J. D. Hem, former district chemist, Albuquerque, and under the general supervision of S. K. Love, chief, Quality of Water Branch. 


\section{ACKNOWLEDGMENTS}

The previous work done by Lasky and Webber was utilized extensively, both in the field and in the preparation of this report. Much appreciation is due Messrs. Rogers and Ellsworth and other residents. of the area, who kindly cooperated in various ways during the investigation.

\section{GEOLOGY AND ITS RELATION TO THE WATER SUPPLY}

\section{LAND FORMS AND DRAINAGE}

The Bill Williams River is formed by the confluence of the Big Sandy and Santa Maria Rivers, about $4 \frac{1}{2}$ miles northeast of the settlement of Alamo (fig. 41). Throughout its length of about 38 miles, the Bill Williams River traverses isolated and practically uninhabited terrain that is typical of the western Arizona desert. For the most part, the river channel is narrow and is confined between rock walls in the precipitous hills and mountains through which it cuts. In a few places where the channel widens and fairly broad flood plains have formed, a few acres of land can be farmed.

From its point of origin the river flows southwest on a comparatively wide flood plain for about 6 miles, then enters a rock narrows that cuts through the north flank of the Buckskin Mountains (pl. 21). The flood plain is bordered on the northwest by the dissected slopes and precipitous spurs of the Artillery Mountains. No major drainage enters the river from this side. For the most part, the hills bordering the river on the southeast are lower and less rugged, and within a few miles from the river they merge into a wide, flat desert plain that extends eastward more than 25 miles. Two major washes, Date Creek and Bullard Wash, drain this plain. Date Creek is an intermittent stream that joins the Santa Maria River 2 or 3 miles upstream from its confluence with the Big Sandy River. Bullard Wash is an ephemeral stream that joins the Bill Williams River slightly upstream from Alamo.

\section{GEOLOGIC HISTORY}

The early geologic history of the area has little bearing upon the ground-water resources. Lasky (Lasky and Webber, 1949, p. 45-48) has discussed the geologic history of the area, particularly the Tertiary period, in considerable detail. Lasky was interested primarily in the manganese deposits and their associated formations, all of which he assigned to the Tertiary system. However, 
the present investigation of ground-water resources is concerned with the principal water-bearing formations, all of which are considered to be of Quaternary age. As far as could be determined, none of the Tertiary formations can be regarded as a potential source of ground water, as they are relatively impermeable. Their importance in relation to ground-water resources depends upon the configuration of their surfaces where they are buried be neath Quaternary sediments.

There seems to be little doubt that post-Tertiary faulting formed a basin in the area. Extensive deposits of lake-bed clays provide evidence that the basin was closed before their deposition. Quaternary lavas, probably of Pleistocene age, are mentioned by Lasky (Lasky and Webber, 1949, p. 38-39), and it is possible that re- . lated flows closed the basin.

Probably during the Pleistocene epoch, or possibly in early Recent time, the clays were deposited to a considerable depth over the large area that is now drained by Date Creek and Bullard Wash. Apparently through drainage has been established for a comparatively short time, as indicated by the small extent of dissection along Bullard Wash and Date Creek. Although Date Creek is quite deeply entrenched in the clays that underlie the plain, its tributary washes are short and their gradients are steep. Bullard Wash is less deeply entrenched, but the drainage patterns of both streams suggest a short term of existence.

Recent earth movement is indicated by the tilting of the clay beds along Date Creek. Recent faulting probably was responsible for the gap in the Buckskin Mountains through which drainage now passes a short distance downstream from Alamo.

Lasky (Lasky and Webber, 1949, p. 48) states that at present the streams are actively eroding, and that the pediments are being dissected. This statement is true of the area as a whole, but perhaps should be qualified for the main channel of the Bill Williams River. Dissection of the pediments is conspicuous, particularly northwest of the river, and to a lesser extent to the southeast. However, along the river there are no alluvial terraces such as might be expected if the river were deepening its channel. The present topography of the area seems best explained by a hypothesis of rapid downcutting of a narrow outlet channel, probably along lines of weakness developed by faulting. This concept is illustrated in figure 43 . The deep channel cutting probably occurred late in the Pleistocene epoch or at the beginning of the Recent epoch, and was followed by a rapid accumulation of debris along the floor of the channel. Geophysical work indicated that the channel was not extensively widened where it was cut through the Tertiary sedimentary rocks. The cut 


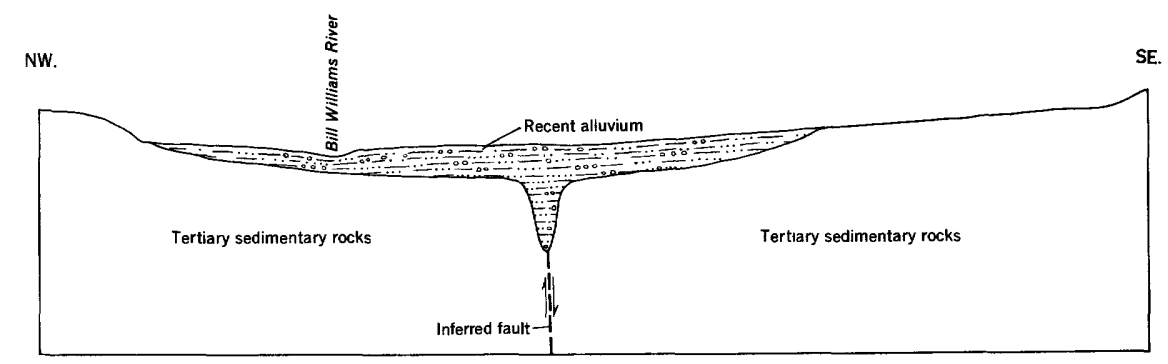

Figure 43. - Diagrammatic section across Bill Williams River near Alamo.

is at present entirely masked by the Recent gravels and sands of the river flood plain.

\section{ROCK FORMATYONS}

The stratigraphic column of formations in the Artillery Peak area is shown in table 1 . None of the formations older than those assigned to the late Pleistocene are considered to be of importance in the storage or transmission of ground water, and therefore are not discussed further in this report.

Southeast of the river the lake-bed clays constitute a significant member of the alluvium assigned to the late Pleistocene (table 1). Although the maximum thickness of the clays was not determined, they are known to be several hundred feet thick a few miles southeast of the mouth of Date Creek. The clay beds become thinner northwestward toward the Bill Williams River and are not present west and northwest of Alamo. The clays have a significant bearing on the ground-water resources of the valley for the reason that they occupy a large area and volume that might otherwise constitute an important source of recoverable ground water.

The sand and gravel of the alluvium of late Pleistocene age occurs in numerous places, but the deposits are thin except in local areas of limited extent. The materials are cemented, some more than others, although usually not to an extent that seriously reduces their permeability.

The sand and gravel of Recent age along the Bill Williams River and its tributary washes is the only deposit in the area that constitutes an important source of ground water. The materials are unsorted and uncemented, and range from boulders to fine sand. Unfortunately, the cross-sectional area of this highly permeable fill is comparatively small (fig. 44). Although the river 
Table 1.-Formations in the Artillery Mountains manganese area

[After Lasky and Webber, 1949, p. 14]

\begin{tabular}{|c|c|c|c|}
\hline Age & Formation & Character & $\begin{array}{l}\text { Thickness } \\
\text { (feet) }\end{array}$ \\
\hline Recent & \multirow{3}{*}{$\begin{array}{l}\text { Later alluvium. } \\
\text { Erosional unconformity } \\
\text { Earlier alluvium. } \\
\text { Angular unconformity } \\
\text { Basalt. }\end{array}$} & $\begin{array}{l}\text { Talus deposits and gravel and sand along } \\
\text { the present drainage. }\end{array}$ & \\
\hline $\begin{array}{l}\text { Late } \\
\text { Pleistocene(?) }\end{array}$ & & Pediment gravel and valley fill. & \\
\hline $\begin{array}{l}\text { Early } \\
\text { Pleistocene(?) }\end{array}$ & & $\begin{array}{l}\text { Massive fine-grained to vesicular glassy } \\
\text { basalt. }\end{array}$ & $0-350+$ \\
\hline \multirow[t]{2}{*}{$\begin{array}{l}\text { Late } \\
\text { Pliocene(?) }\end{array}$} & \multirow{2}{*}{$\begin{array}{l}\text { Angular uncontormity } \\
\text { Sandtrap conglomerate. } \\
\text { Erosional unconformity } \\
\text { Cobwebb basalt. }\end{array}$} & $\begin{array}{l}\text { Largely light-red to dark-red poorly } \\
\text { sorted conglomerate with discontin- } \\
\text { uous bedding. Includes a prominent } \\
\text { basalt member in the northwest part } \\
\text { of the area. }\end{array}$ & $\begin{array}{l}0 \text { to possibly } \\
2,000\end{array}$ \\
\hline & & Massive aphanitic vesicular basalt. & $0-250+$ \\
\hline $\begin{array}{l}\text { Early } \\
\text { Pliocene(?) }\end{array}$ & \multirow{3}{*}{$\begin{array}{l}\text { Chapin Wash formation. } \\
\text { Angular unconformity } \\
\text { Volcanic rocks. } \\
\text { Angular unconformity } \\
\text { Artillery formation. }\end{array}$} & $\begin{array}{l}\text { Alluvial-fan and playa deposits-fan- } \\
\text { glomerate, conglomerate, sandstone } \\
\text { siltstone, mudstone, clay and lime- } \\
\text { stone; in part gypsiferous. The prin- } \\
\text { cipal manganese-bearing formation. }\end{array}$ & $\begin{array}{l}0 \text { to possibly } \\
1,500 \text { or } \\
\text { more }\end{array}$ \\
\hline Miocene(?) & & $\begin{array}{l}\text { Tuffs, breccias, and flows, rhyolitic } \\
\text { to andesitic. }\end{array}$ & $1,800+$ \\
\hline $\begin{array}{l}\text { Early } \\
\text { Eocene(?) }\end{array}$ & & $\begin{array}{l}\text { Conglomerate, arkose, sandstone, } \\
\text { shale, limestone, a small amount } \\
\text { of clay and tuff, and a widespread } \\
\text { basalt member; in large part highly } \\
\text { indurated. }\end{array}$ & $2,500+$ \\
\hline Paleozoic(?) & \multirow{2}{*}{ Angular unconformity } & $\begin{array}{l}\text { Limestone, shale, and quartzite, in } \\
\text { part metamorphosed. }\end{array}$ & \\
\hline Pre-Cambrian & & $\begin{array}{l}\text { Granite, gneiss, microbreccia, and } \\
\text { subordinate schist; includes some } \\
\text { monzonitic rock in the Rawhide } \\
\text { and Buckskin Mountains that may } \\
\text { be younger than pre-Cambrian. }\end{array}$ & \\
\hline
\end{tabular}

flood plain is wide, relatively impermeable Tertiary sedimentary rocks lie close to the surface, and the Recent sand and gravel is shallow except along the flood-cut trench. 


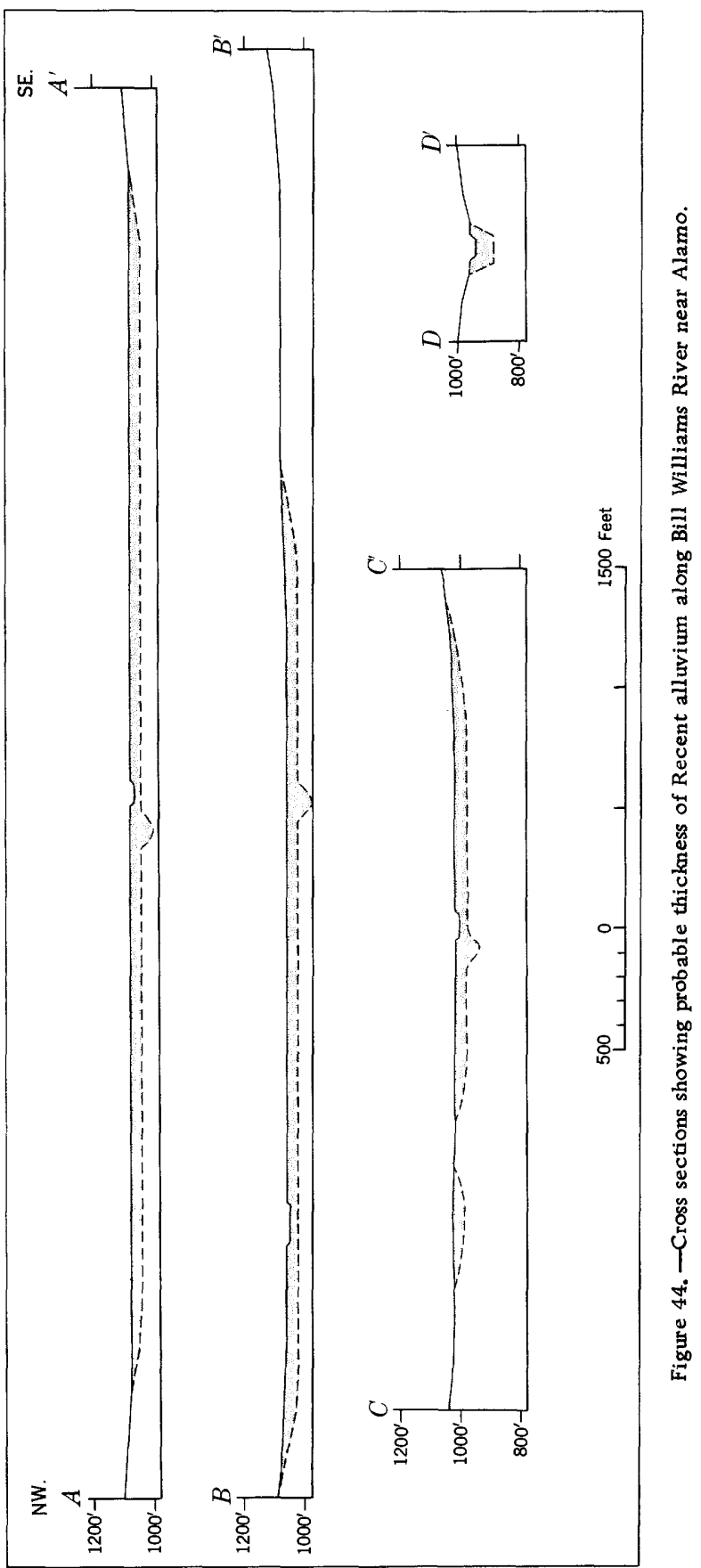




\section{STRUCTURE}

Because of the low topographic relief and the lack of rock exposures in much of the area southeast of the Bill Williams River, structural features are, on the whole, less conspicuous than in the area northwest of the river. Folding is prominent where Tertiary sedimentary rocks are exposed just south of the junction of the Santa Maria and Big Sandy Rivers, and also along the east bank of the Bill Williams River immediately upstream from the Alamo gaging station. In both these areas the bedded sedimentary rocks of the Artillery and Chapin Wash formations exhibit a multitude of minor deformations that probably represent compensatory adjustments related to major faulting along the channel of the Bill Williams River. Local composite folding is characteristic of these formations. Variable dips in the Sandtrap conglomerate indicate similar composite folding, but the indistinct bedding in the conglomerate makes the structural oharacteristics less conspicuuous. Faults were found in the Artillery and Chapin Wash formations east of the river, but none could be traced very far, and none showed large displacement. This fact and the lithologic characteristics of the Tertiary formations in the area minimize or preclude the probability of important ground-water storage along open fractures or fault zones.

Quaternary valley fill lies at the surface in much of the area extending several miles southeastward from the Bill Williams River. It was thought possible that the investigation might reveal the presence of alluvium-filled synclinal troughs in the relatively impermeable Tertiary sedimentary rocks underlying at least part of this area. Small springs in sec. 36, T. 11 N., R. 13 W. (table 3 ), emerging along the contact between the Chapin Wash formation and the overlying Quaternary sediments, suggested overflow from a ground-water reservoir. However, electrical-resistivity probes in the most promising area indicated that the confining trough was too shallow to constitute a large reservoir.

The presence of a major fault zone along the channel of the Bill Williams River has been reasonably well established by the logs of test holes drilled by the Corps of Engineers at the Alamo dam site. These holes showed a thickness of more than 80 feet of sand, gravel, and boulders in a channel that is less than 60 feet wide in places. The scouring action of torrential floods could scarcely have made such a cut in the highly resistant metamorphic rocks at the dam site unless it had followed lines of structural weakness. Although the channel alinement through the narrows lacks the long tangents that might indicate control by longitudinal faults, the pattern may have been complicated by offsetting along later cross faults. 


\section{GEOPHYSICAL INVESTIGATIONS}

Electrical-resistivity surveys were made in order to estimate the thickness of alluvial fill. The instruments were of the type described by Heiland (1940, p. 644-645). Owing to high earth-toelectrode resistance and low earth resistivity in the region, relatively high voltages were required to produce a measurable current. Commercial equipment previously used was inadequate; therefore, a heavier instrument, designed and constructed by H. E. Skibitzke and A. E. Robinson, was used.

\section{DESCRIPTION OF EQUIPMENI}

The equipment was designed to carry up to 500 volts, and included a commutator having broader brush contacts and wider insulating gaps than were available commercially. A portable motorgenerator was incorporated into the unit as a source of power be cause the commutator could not readily be turned at a constant speed by hand. The instrument panel was constructed with extraheavy switches, heavy wire, meters capable of withstanding occasional overload, and a wide separation of circuits to prevent arcing during periods of input of high voltage. Heavy-duty 45-volt " $B$ " batteries connected in series provided input current.

A power-operated wire retriever was installed in the equipment truck to lay and retrieve wire. With this retriever it was possible to lay 1 mile of wire in 15 minutes and to retrieve it in $20 \mathrm{~min}$ utes. The field stakes were made of copper-clad steel, 24-inches long and 1 inch in diameter.

\section{FIELD OPERATIONS}

Three lines of probes were run to furnish data for cross sections of subsurface resistivities. Three additional probes were run to determine the thickness of alluvium in sec. 36, T. $11 \mathrm{~N}$., R. $13 \mathrm{~W}$. The three lines of probes were made in a direction from northwest to southeast. The probe numbers and locations are shown on plate 21 . The first line was about 2 miles upstream from Alamo, the second was at Alamo, and the third was about a mile downstream, near the entrance to the box canyon.

The field work was made difficult by the extreme variations of surface resistivity within the river channel and by the dense plant growth. The Recent fill in the channel is composed of coarse sand and gravel and many large boulders. Within short distances the water content of the material ranged from very low to very high. 
This condition caused surface resistivities to range widely and made it extremely difficult to balance the electrode resistances. The many boulders made the driving of the electrodes troublesome. When surface resistivities were high it was necessary to use more than 300 volts to maintain adequate current flow.

A stake configuration, including one very long line, was used so that current input could be established at "infinity." For each individual probe two electrode stakes were driven, one at the instrument and the other at the far end of the "infinite" line; these stakes were not moved during the probe. Two other electrode stakes were used. These stakes were moved outward to equal distances from the fixed electrode at the instrument for each depth-resistivity determination. In this way only two assistants were needed to drive the movable electrodes. In addition to the two assistants, the party included an instrument operator and a field computer. In general, all the probes along each section, $A-A^{\prime}$ (pl. 21) for example, were made with a single setting of the infinite electrode.

For eachstake separation a reading was taken, using the movable electrode on the left and the infinite electrode to conduct current from the batteries to the earth, and making potential measurements with the center electrode and the movable electrode on the right. A second reading was taken, using the movable electrode on the right and the infinite electrode for current input and the remaining two electrodes for the potential reading. The average of the two resistivities, computed from the readings, was taken as the apparent resistivity for the stake separation in the vicinity of the center electrode. The depth in feet, which is equal to the distance from the center stake to either of the two movable stakes, was plotted against resistivity in ohm-centimeters on logarithmic paper in the field. Thus, a resistivity curve was available for study and interpretation as soon as a probe was completed.

\section{INTERPRETATION OF RESULTS}

Owing to the lack of uniformity of surface materials in the area, there were irregularities in the shape of some of the curves. In general, however, it was possible to match them with the theoretical three-layer curves of Wetzel and McMurry (1937). Using the theoretical curves, the depths to the average interface between layers of different resistivity were estimated, and the average apparent resistivity of each layer was determined. Using these data and the available well data, the cross sections shown in $\mathrm{fig}-$ ure 44 were plotted. 
The probes along section $A-A^{\prime}$ (pl, 21) north of Alamo indicated that on both sides of the river the Recent alluvium is resting on the Tertiary conglomerate. In the central part of the channel the resistivities approached infinity at very shallow depths, making interpretation below the interface impossible. Hence, the thickness of the materials below the interface could not be determined.

The probes along section $B-B^{\prime}$ indicated that the channel alluvium is resting on the conglomerate. In these probes, high resis tivities in the channel alluvium were interpreted to represent coarse, unsorted sand and gravel.

\section{TEMPERATURE SURVEY}

Geophysical probe 7 (pl. 21) showed an anomaly of extremely low resistivity near the surface. In addition, strong earth currents and a negative area at the probe were observed. According to Heiland $(1940$, p. 680) this combination possibly indicates springs or an ore deposit. To determine if subsurface inflow was accurring, temperature surveys of the river water were made during July 1951 in the reach from about $1 \frac{3}{4}$ miles northeast of Alamo to the gaging station below Alamo. Temperature measurements were made at 100-foot intervals. The first survey was made before daylight to determine if the temperatures in the channel were affected by warm subsurface inflow. The second survey was made about midday to detect the possible presence of cool subsurface inflow.

The surveys indicated no detectable inflow of ground water warmer or cooler than normal for the area. There was no increase in stream discharge attributable to a subsurface spring in the vicinity of probe 7 , nor was there a change in the chemical character of the surface water. It was concluded therefore, that the electrical-resistivity anomaly did not represent subsurface inflow.

\section{SURFACE-WATER RESOURCES}

Part of the runoff into the area is measured at a gaging station near the mouth of the Santa Maria River (fig. 41). Representative data from this station are given in table 2. All the surface-water records for the river are published annually in the water-supply papers entitled "Surface water supply of the United States, part 9, Colorado River basin." In addition, low flows are measured occasionally at the mouth of the Big Sandy River. ${ }^{1}$

1These measurements are on file in the district office of the Surface Water Branch, U. S. Geological Survey, at Tucson, Ariz. 


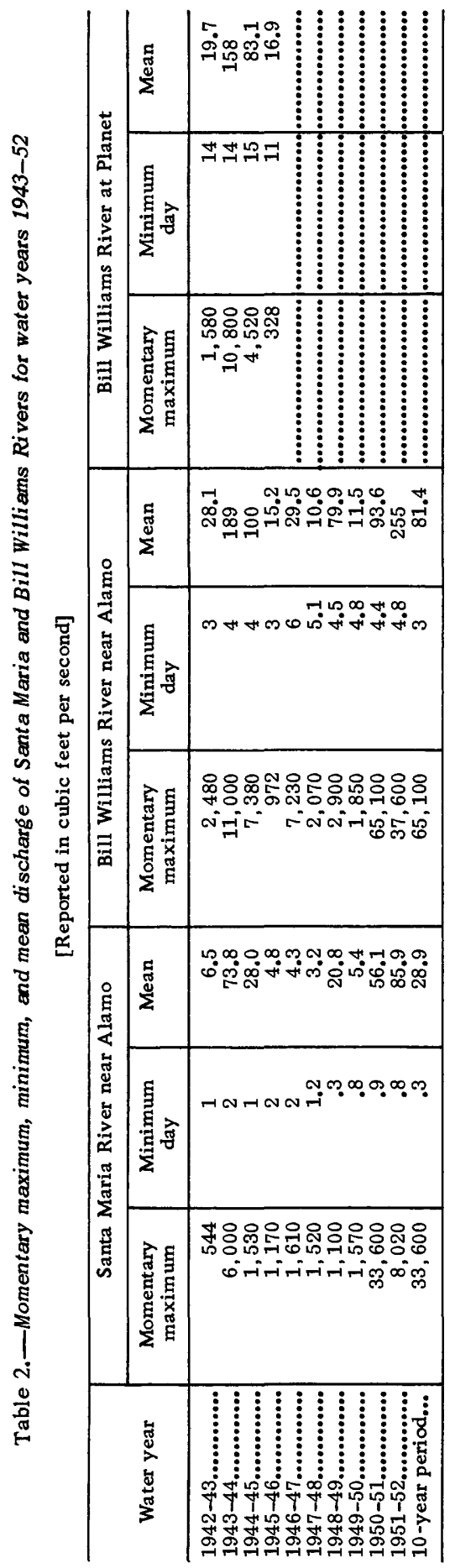


As shown in table 2, the Bill Williams River is perennial at its point of origin. About $1 \frac{1}{2}$ miles downstream the river goes dry at low stages, owing to an increase in the cross-sectional area of the Recent alluvium and a consequent greater capacity for underflow. Surface flow generally begins again about a mile upstream from Alamo, and the river is perennial from there to a point several miles downstream from the Alamo gaging station.

The surface flow of the Bill Williams River at the Alamo gaging station is subject to tremendous fluctuations. Flows as low as 3 cfs have been recorded in the 10-year period 1943-52 (table 2). One of the largest recorded floods occurred as recently as August 1951, when runoff from summer rains resulted in a peak discharge of more than 65,000 cfs. High-water marks as much as 45 feet above the present stream level near the station show that there have been floods of considerably greater volume, but no exact figures are available.

Between 1928 and 1946 a gaging station was operated at Planet, 28 miles downstream from the Alamo gaging station. Representative data from the Planet station are given in table 2. Minimum flow in the period 1943-46 was $11 \mathrm{cfs}$. Peaks of more than 100,000 cfs have been reported at Planet on three occasions, and a flood in 1891 was estimated to have reached a peak discharge of 200,000 cfs.

\section{GROUND-WATER RESOURCES}

\section{OCCURRENCE AND MOVEMENT}

Ground water occurs principally in the Recent sand and gravel along the channel of the Bill Williams River. Minor amounts of ground water occur in some of the late Pleistocene(?) gravels, which are relatively thin and of small areal extent. Ground water is present to some extent in all the Tertiary formations, both sedimentary and volcanic, but their permeability is extremely low. Thus, the Recent sand and gravel along the river channel appears to be the only potential aquifer in the area.

Terms used to describe the water-bearing properties of the Recent alluvium are defined in many reports and papers of the U. S. Geological Survey. Among the recent papers is one by Brown (1953). 


\section{STORAGE}

In estimating the size of the basin in which ground water is stored, it was necessary to adduce evidence from the geology of the area, from wells and test bores in the channel, and from the electrical-resistivity data. No single method of approach gave a satisfactory figure, and even the aggregate result of the several methods was not fully satisfactory. It is believed, however, that sufficient information has been gathered to justify the conclusions expressed below.

The river channel in this area probably coincides with a major faultzone, and rapiderosion along this line of structural weakness has resulted in the cutting of a deep, narrow notch to a base level well below the present flood plain (fig. 43).

The gene ralized conclusions drawn from the electrical-resistivity work were in accord with those formed from geologic and hydrologic evidence. On the basis of all the data available, computations were made to determine the total volume of Recent alluvium in the 6 -mile reach of the Bill Williams River between the confluence of the two parent streams and the Alamo gaging station. This volume of alluvium is estimated to be about 100,000 acre-feet.

Laboratory tests were made on 11 samples of water-bearing materials and pumping tests were made on 5 wells to determine the coefficient of permeability and the specific yield. On the basis of these tests the specific yield was estimated to be between 0.10 and 0.15 . This is about equal to the coefficient of storage in the Alamo area. Thus, the quantity of ground water stored in the alluvium in the reach is considered to be between 10,000 and 15,000 acre-feet. However, it would not be physically possible to withdraw this quantity of ground water from storage by means of wells.

\section{RECHARGE}

The ground water in the Recent alluvium is recharged principally from flow in the river. In fact, as the river has never been dry at the gaging station during the period of record, recharge is being rejected because the aquifer is saturated there. There are periods each year, however, when part of the aquifer upstream from the station becomes unwatered, owing to natural discharge by evapotranspiration.

Another source of recharge to the aquifer is rainfall directly on the land surface. In an average year about 1,700 acre-feet of water falls as rain, on the basis of a rate of 8 inches on about 2,500 
acres. Part of this is retained in the soil and discharged by evapotranspiration, and part reaches the water table.

Combined underflow of the Big Sandy and Santa Maria Rivers, on the basis of incomplete data, is about $0.8 \mathrm{cfs}$ or about 600 acrefeet per year.

Although irrigation was not extensive in the area at the time the investigation was made, some recharge undoubtedly occurs from downward seepage of water applied to fields. This factor at present is negligible, but will be more important if additional land is cultivated.

\section{DISCH ARGE}

Ground water is discharged from the basin by (1) surface flow, (2) underflow, (3) transpiration by phreatophytes, (4) evaporation, (5) pumping for irrigation, and (6) pumping for domestic use. The first means of discharge is the largest and can be measured directly (table 2). The others have been estimated and, although the estimates may include a considerable margin of error, the total quantities involved are comparatively small, about 1,000 acrefeet in an average year.

Underflow.-Discharge by underflow along the Bill Williams River at the lower end of the Alamo basin is important, because the surface discharge of the river at low-flow stages is insufficient to supply the water needed for large-scale mining and milling operations, and because no provision has been made for storage of flood water. Therefore, water would have to be obtained from underground sources during low-flow stages. It has been noted that the storage capacity of the underground reservoir in the Alamo area is limited, which lends added importance to the quantity of underflow.

Data from the cross sections (fig. 43), the topographic maps, the laboratory determinations of permeability, the pumping tests, and, for section $D-D^{\prime}$, the data on borings at the dam site, were used to estimate the underflow at each of the sections.

\begin{tabular}{c|r|r|r|r}
\hline $\begin{array}{c}\text { Cross section } \\
\text { (location } \\
\text { shown on p1. 21) }\end{array}$ & $\begin{array}{c}\text { Width } \\
\text { (miles) }\end{array}$ & $\begin{array}{c}\text { Gradient } \\
\text { (feet per } \\
\text { mile) }\end{array}$ & \multicolumn{1}{|c|}{$\begin{array}{c}\text { Transmissibility } \\
\text { (gpd/ft) }\end{array}$} & \multicolumn{1}{|c}{$\begin{array}{c}\text { Underflow } \\
\text { (gpd) }\end{array}$} \\
\hline$A-A^{\prime}$ & 0.76 & 16 & 125,000 & $1,500,000$ \\
$B-B^{\prime}$ & .50 & 20 & 100,000 & $1,000,000$ \\
$C-C^{\prime}$ & .34 & 33 & 67,000 & 750,000 \\
$D-D^{\prime}$ & .01 & 53 & 1150,000 & 80,000 \\
\hline
\end{tabular}

1Estimated from comparison of data from test holes drilled at dam site by Corps of Engineers in 1939 with those from exposures and wells in area upstream. 


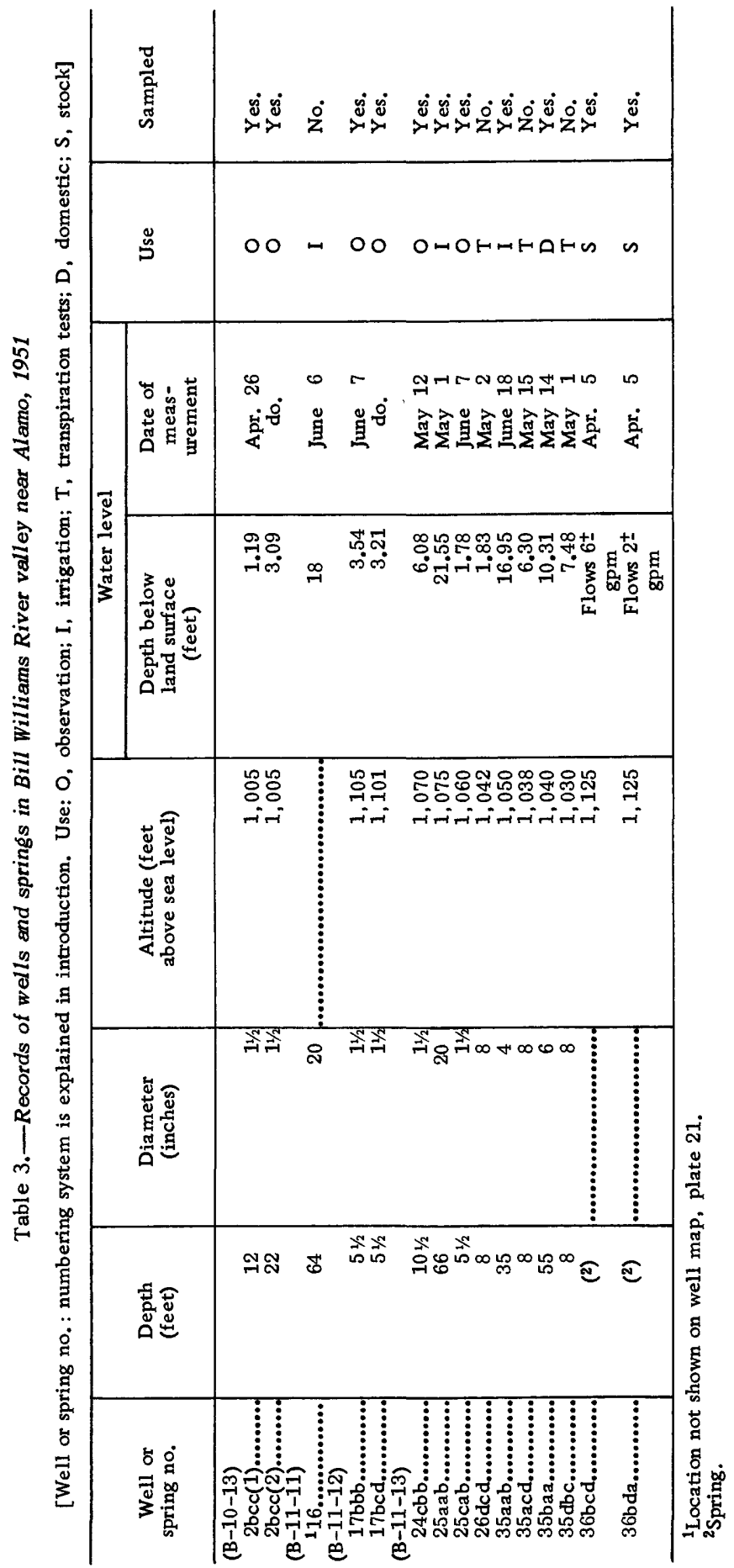


At the junction of the Santa Maria and Big Sandy Rivers the underflow is less than $500,000 \mathrm{gpd}$. It is interesting to note that the underflow is greatest where surface flow is least, and that the quantity of underflow becomes progressively less into the box canyon downstream from the gaging station. The surface flow gradually increases in this reach.

Transpiration by phreatophytes. - The data from continuous water-level records in three "transpiration" wells (table 3), and from a physical inventory of phreatophyte growth. $\because \mathrm{ere}$ combined in arriving at an estimate of annual discharge of ground water from the area by transpiration. The big flood of August 1951 swept away part of the phreatophytes and considerably reduced the natural discharge by transpiration.

Using the methods described by Gatewood and others (1950, p. 139-154), transpiration losses in the area were computed for the year 1951. The wells were placed in operation in April and were destroyed by the flood in August, and therefore the data had to be extrapolated by methods developed by Gatewood and others (1950, table 33 ) to stimate transpiration in the full growing season. On the basis of the plant density observed in 1951, the transpiration is estimated to be about 700 acre-feet annually.

Evaporation.-No experiments were made to determine direct evaporation of ground water from wetted sands and from the river sur face. An estimate of these losses was made by applying data from the Safford Valley (Gatewood and others, 1950, p. 50), indicating that direct evaporation of ground water in the area is about 150 acre-feet per year.

Pumping.-Probably no more than 40 acres of land was irrigated in the area in 1951, and it was estimated that about 150 acre-feet of water was withdrawn from the ground-water reservoir for that purpose. Withdrawals of ground water for domestic use were negligible.

\section{WATER-TABLE FLUCTUATIONS}

Field work in the area was done during the dry season, when the water table was near minimum levels. Through part of the reach the water table was above the level of the stream, bed, resulting in surface flow. In some places the water table was a few inches to a few feet below the stream bed, and surface flow disappeared. Sand points were driven at various places along the river channel and flood plain (table 3 ) for periodic water-level measurements. The measurements inaicated no significant changes in water levels during the period of the investigation. 


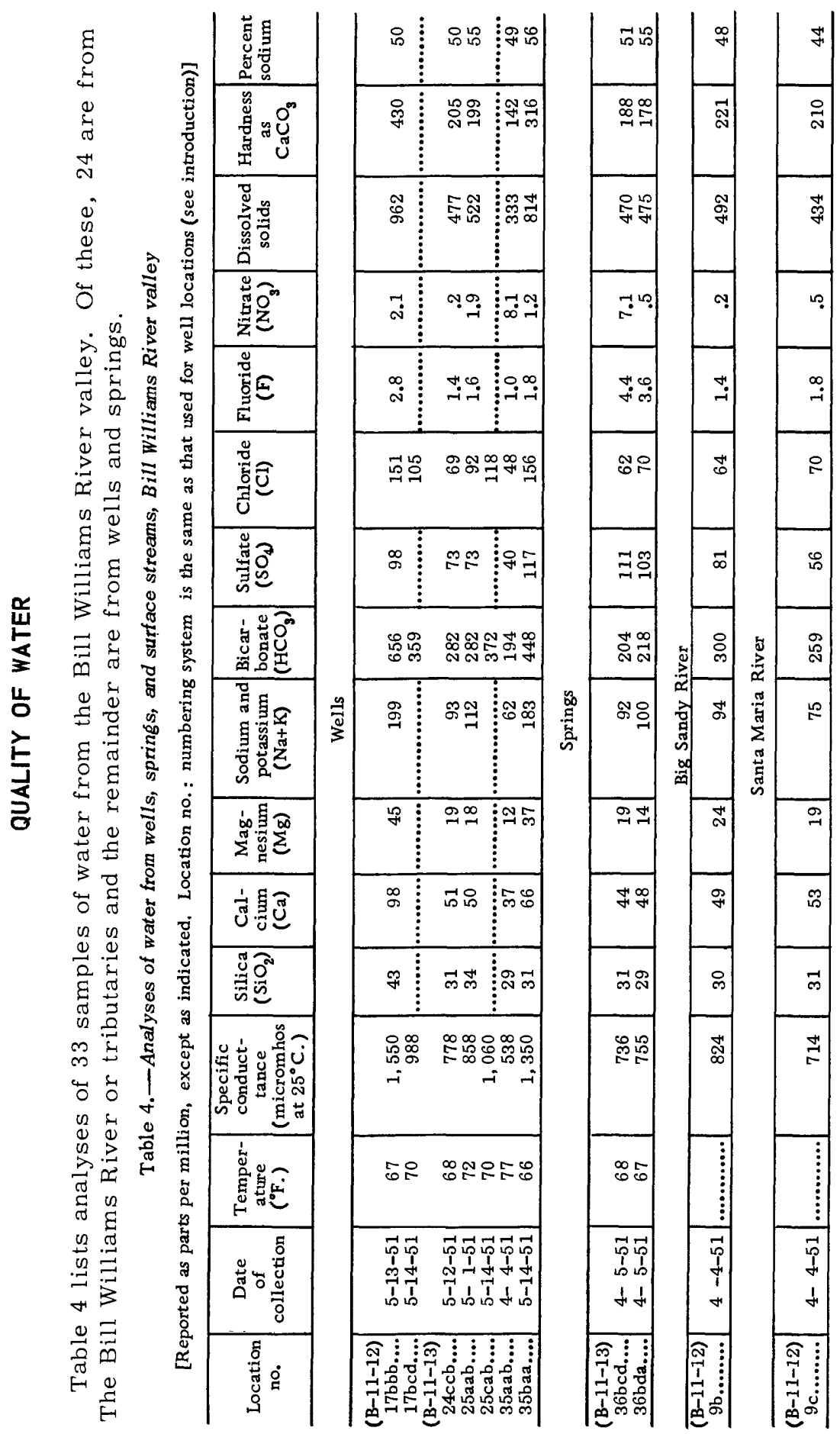


WATER RESOURCES, BILL WILIAMS RIVER VALLEY, ARZONA

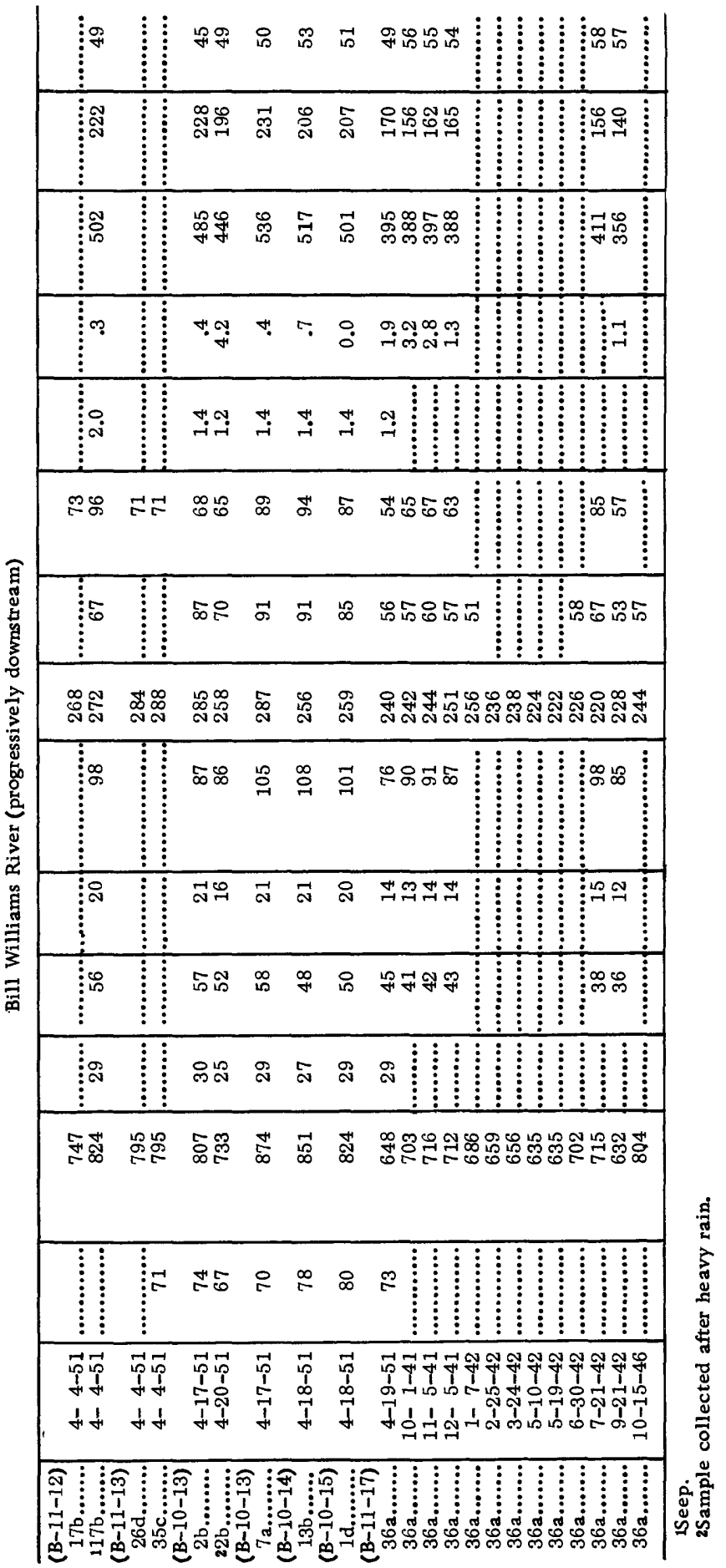




\section{SURFACE WATER}

Available analyses of stream samples are listed in table 4 . The water of the Bill Williams River contains moderate amounts of dissolved mineral matter and is fairly hard. On the basis of chemical quality, most of it is considered suitable for irrigation and domestic use (Wilcox, 1948, p. 26-27; U. S. Public Health Service, 1946). The samples bearing dates of collection of April 4, 1951, and between April 17 and April 20, 1951, were collected during a time of low flow.

\section{GROUND WATER}

Of the 9 analyses of water from wells and springs (table 4), 7 are of samples from wells in the Recent alluvium along the river. These analyses indicate that the ground water is similar in chemical character to the surface water of the stream, and is slightly more mineralized. This leads to an assumption that the source of the ground water is primarily infiltration of river water, probably at some point farther upstream. Except for fluoride, most of the samples conform to the limits established by the U. S. Public Health Service (1946) for waters used for drinking on interstate common carriers.

\section{POTENTIALITIES FOR WATER DEVELOPMENT}

The records of surface-water flow at the Alamo gaging station indicate that the annual mean discharge of the Bill Williams River at that place exceeds the $7 \frac{1}{2} \mathrm{cfs}$ that has been estimated would be needed if a manganese mill and a mining community were established. However, there are periods of sustained low flow in the river every year, and during some periods the minimum flow is as low as $3 \mathrm{cfs}$.

In order to evaluate the approximate proportion of each year that the river is likely to supply the needed $7 \frac{1}{2} \mathrm{cfs}$, table 5 and

Table 5.-Percent of time in which flow equaled or exceeded indicated discharge, Bill Williams River near Alamo, 1942-52

\begin{tabular}{|c|c|c|c|c|c|}
\hline $\begin{array}{c}\text { Discharge } \\
\text { (cfs) }\end{array}$ & $\begin{array}{l}\text { Percent of } \\
\text { time }\end{array}$ & $\begin{array}{c}\text { Discharge } \\
\text { (cfs) }\end{array}$ & $\begin{array}{c}\text { Percent of } \\
\text { time }\end{array}$ & $\begin{array}{c}\text { Discharge } \\
\text { (cfs) }\end{array}$ & $\begin{array}{l}\text { Percent of } \\
\text { time }\end{array}$ \\
\hline $\begin{array}{l}1 \ldots \ldots \ldots \ldots \\
2 \ldots \ldots \ldots \ldots \ldots \\
3 \ldots \ldots \ldots \ldots \ldots \\
4 \ldots \ldots \ldots \ldots \\
5 \ldots \ldots \ldots \ldots \\
6 \ldots \ldots \ldots \ldots \\
7 \ldots \ldots \ldots \ldots\end{array}$ & $\begin{array}{r}100 \\
100 \\
99 \\
94 \\
82 \\
72 \\
64\end{array}$ & $\begin{array}{r}8 \ldots \ldots \ldots \ldots \ldots \\
9 \ldots \ldots \ldots \ldots \ldots \\
10 \ldots \ldots \ldots \ldots \\
11 \ldots \ldots \ldots \ldots \ldots \\
12 \ldots \ldots \ldots \ldots \ldots \\
13 \ldots \ldots \ldots \ldots \ldots \ldots \\
14 \ldots \ldots \ldots \ldots \ldots \ldots\end{array}$ & $\begin{array}{l}55 \\
46 \\
39 \\
34 \\
31 \\
29 \\
27\end{array}$ & $\begin{array}{l}15 \ldots \ldots \ldots \ldots \ldots \\
16 \ldots \ldots \ldots \ldots \ldots \\
17 \ldots \ldots \ldots \ldots \ldots \ldots \\
18 \ldots \ldots \ldots \ldots \ldots \\
19 \ldots \ldots \ldots \ldots \ldots \\
20 \ldots \ldots \ldots \ldots \ldots\end{array}$ & $\begin{array}{l}26 \\
25 \\
24 \\
23 \\
22 \\
20\end{array}$ \\
\hline
\end{tabular}




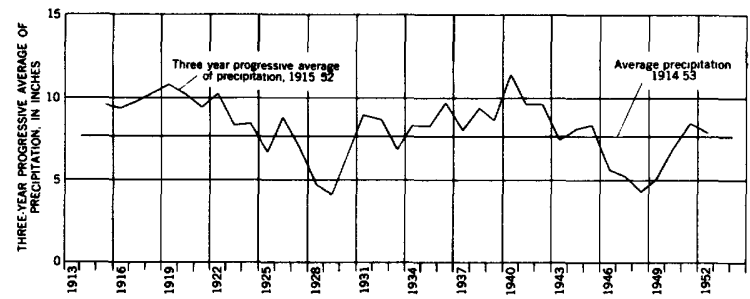

Figure 45. - Three-year progressive average of precipitation at Salome, Ariz., for the period 1914-53.

figure 45 were prepared. Table 5 indicates the percent of days during the period 1942-52 in which flow equaled or exceeded specific discharges. Figure 45 is a graph of rainfall at Salome, Ariz., for the period of record, 1914-53. In order to show trends, if any, the data were plotted as a 3-year progressive average. In this graph the effect of an extremely wet or dry year is reduced by averaging the figures for that year with those for the respective preceding and succeeding years. Inspection of the graph indicates that during the period 1942-52, years of below-average precipitation predominated. Thus, it is likely that use of the streamflow data for the period 1942-52 (table 5) to evaluate future conditions would lead to conservative conclusions.

According to table 5, discharge of the Bill Williams River at the Alamo gaging station equals or exceeds $7 \frac{1}{2} \mathrm{cfs}$ about 60 percent of the time and amounts to $3 \mathrm{cfs}$ or more about 90 percent of the time. For about 40 percent of the time, therefore, the surface flow of the stream is inadequate to supply the entire $7 \frac{1}{2} \mathrm{cfs}$, and supplemental means of providing water are required. There are two low-flow seasons each year, normally in the periods MayJune and September-October.

According to table 5 the surface flow of the river would need to be supplemented by over $4 \frac{1}{2} \mathrm{cfs}$ about 1 percent of the time, by $3 \frac{1}{2}$ to $4 \frac{1}{2} \mathrm{cfs}$ an additional 5 percent of the time, and so forth. The following tabulation indicates that about 800 acre-feet per year of supplementary water is needed on the average:

\begin{tabular}{|c|c|c|c|}
\hline $\begin{array}{l}\text { Supplementary } \\
\text { supply required } \\
\text { (cfs) }\end{array}$ & $\begin{array}{l}\text { Percent of } \\
\text { time } \\
\text { required }\end{array}$ & $\begin{array}{l}\text { Number of } \\
\text { days } \\
\text { required }\end{array}$ & $\begin{array}{l}\text { Quantity } \\
\text { required } \\
\text { (acre-feet) }\end{array}$ \\
\hline $\begin{array}{l}\text { More than } 4 \frac{1}{2} 1 \\
3 \frac{1}{2}-4 \frac{1}{2} 2 \\
2 \frac{1}{2}-3 \frac{1}{2} \\
1 \frac{1}{2}-2 \frac{1}{2} \\
\frac{1}{2}-1 \frac{1}{2} 2 \\
\text { Less than } \frac{1}{2}\end{array}$ & $\begin{array}{r}1 \\
5 \\
12 \\
10 \\
8 \\
4\end{array}$ & $\begin{array}{c}4 \\
18 \\
44 \\
36 \\
29 \\
15\end{array}$ & $\begin{array}{r}40 \\
162 \\
308 \\
180 \\
87 \\
15\end{array}$ \\
\hline Total & 40 & 146 & 792 \\
\hline
\end{tabular}

1Used $5 \mathrm{cfs}$.

${ }^{2}$ Used highest discharge in range given. 
The possible measures that could be taken to provide this supplementary water include the following: (1) Reduce ground-water losses by the destruction of nonbeneficial phreatophytes; (2) withdraw water from wells drilled at intervals along the valley upstream from the gaging station; (3) construct an underflow dam and an infiltration gallery near the gaging station; (4) construct a surface-water dam in the box canyon below the gaging station; and (5) develop a ground-water supply downstream from the box canyon. Each of these possible measures is discussed in the following paragraphs.

Destruction of phreatophytes. - Destruction of the nonbeneficial phreatophytes in the river-bottom area would eliminate the major portion of ground-water losses caused by transpiration. The net result would be an increase in the flow of the Bill Williams River at Alamo gaging station. As phreatophytes use ground water only during the growing season, and as at least one of the annual periods of low flow (May-June) occurs at the height of the growing season, reduction of transpiration losses would result in an increase of the minimum flow of the stream. It is estimated that if the phreatophytes were destroyed, the surface flow of the stream would provide all but about 200-300 acre-feet per year of the needed minimum supply of $7 \frac{1}{2} \mathrm{cfs}$.

Wells. - The quantity of ground water stored in the vicinity of Alamo was estimated to be between 10,000 and 15,000 acre-feet; this ground-water reservoir is considered to be capable of providing the needed supplemental supply of 800 acre-feet per year. However, the ground-water reservoir is shallow, and several wells would be required. If a program of well drilling were undertaken, the characteristics of the aquifer in the vicinity of the first well should be determined before sites for subsequent wells are selected. A pumping test would supplement the preliminary data collected during the present investigation and would provide a basis for an adequate well-spacing pattern.

Infiltration gallery. - A subsurface dam at the upstream end of the box canyon would provide a means of intercepting the entire underflow; and an infiltration gallery, if placed at the lowest level of the bedrock channel, would make available all the underflow as well as some water from storage in the Alamo basin. However, owing to the narrow underflow channel, withdrawal of the entire $7 \frac{1}{2} \mathrm{cfs}$ might not be possible from such an installation during some periods. It is probable, therefore, that additional measures would be required. The eradication of nonbeneficial phreatophytes or the construction of wells upstream from the gaging station, or both, should be adequate to supplement an underflow dam and infiltration gallery. 
Surface-water reservoir. - The box canyon below the gaging station provides what appears to be an ideal dam site, although consideration of the feasibility of a dam and reservoir was beyond the scope of the investigation. The surface-water records indicate that, during the period of record, runoff was sufficient to supply a continuous draft of $7 \frac{1}{2} \mathrm{cfs}$.

Supplemental ground-water supply downstream.-A reconnaissance was made to evaluate the possibilities of developing ground wate $r$ in the area between the Alamo gaging station and Planet. A seepage run was made in April 1951 along 30 miles of the river channel between Alamo and a rock constriction about a mile downstream from Planet. At that time the surface flow in the river was near a minimum. The run was made for the purpose of locating possible areas of recharge or loss along this reach of the river, and to gather information concerning geology, phreatophyte growth, and water-use installations directly related to or dependent upon streamflow or underflow. Discharge measurements were made at various places along the river, and samples of the water were collected at each measuring point (table 4). Results of the measurements are shown in the following tabulation:

\begin{tabular}{|r|c|c|}
\hline Location & $\begin{array}{c}\text { Miles upstream from } \\
\text { Lake Havasu }\end{array}$ & $\begin{array}{c}\text { Discharge } \\
\text { (cfs) }\end{array}$ \\
\hline 1(B-10-13)2b & 32.1 & 8.94 \\
$7 \mathrm{a}$ & 27.8 & 6.34 \\
$(\mathrm{~B}-10-14) 13 \mathrm{~b}$ & 25.3 & .47 \\
$14 \mathrm{a}$ & 24.9 & 0 \\
$(\mathrm{~B}-10-15) 1 \mathrm{~d}$ & 19.0 & 21.07 \\
$12 \mathrm{~b}$ & 18.0 & 0 \\
3(B-11-17)36a & 4.0 & 10 \\
\hline
\end{tabular}

1 Alamo gaging station.

Diversions for irrigation.

3Planet.

The differences in surface flow shown in the preceding table are due, for the most part, to geologic and topographic factors and do not represent large gains or losses in combined surface flow and underflow. From mile 32.1 to mile 25.3 the river channel follows a narrow gorge in pre-Cambrian metamorphic rocks, and most of the underflow is forced to the surface. At mile 25.3 and again at mile 19 the rock channel opens into comparatively wide flood plains that readily absorb most of the surface flow. At mile 4 the river enters another constricted channel; surface flow begins abruptly less than a mile upstream from the narrows. Throughout the reach from mile 19 to mile 5 the river channel is not constricted, and the entire discharge during dry periods is carried as underflow. 
A wide tributary valley extends northward from Planet toward Yucca, but no estimate was made of the quantity of ground-water inflow from it into the Bill Williams River valley. Reconnaissance information suggests that the quantity probably is not large. However, the Bill Williams River valley and the lower end of this tributary valley may form a ground-water storage reservoir of much larger capacity than that in the vicinity of Alamo. In the event that successful operation of the manganese mine and mill near Artillery Peak requires more water than can be developed in that locality, the possibility of obtaining a supplemental supply from this downstream area might merit serious consideration. Transportation of water from the Planetarea would involve expensive pipeline construction over a distance of about 25 miles and a maximum pumping lift of almost 400 feet.

\section{PRIOR RIGHTS TO WATER OF BILL WILLIAMS RIVER}

Plans for the use at Alamo of water from the Bill Williams River, either surface flow or underflow, must take into consideration the established water rights, even though in the aggregate these rights may not be large. As this subject is of a legal nature, it was considered to be beyond the scope of the investigation.

\section{LITERATURE CITED}

Brown, R. H., 1953, Selected procedures for analyzing aquifer test data: Jour. Am. Water Works Assoc., v. 45, no. 8, p. 844-866.

Dean, R. S., and others, 1934a; Manganese; its occurrence, milling, and metallurgy, pt. 1: U. S. Bur. Mines Inf. Circ. 6768 , p. 39-41.

1934b; Manganese; its occurrence, milling, and metallurgy, pt. 3: U. S. Bur. Mines Inf. Circ. 6770, p. 168.

Gatewood, J. S., and others, 1950, Use of water by bottom-land vegetation in lower Safford Valley, Ariz.: U. S. Geol. Survey Water-Supply Paper 1103, 210 p.

Heiland, C. A., 1940, Geophysical exploration: New York, Prentice-Hall, 1013 p.

Lasky, S. G., and Webber, B. N., 1949, Manganese resources of the Artillery Mountains region, Mohave County, Ariz.: U. S. Geol. Survey Bull. 961, 86 p.

Lee, W. T., 1908, Geologic reconnaissance of part of western Arizona: U. S. Geol. Survey Bull. 352, $96 \mathrm{p}$.

U. S. Public Health Service, 1946, Drinking-water standards, 1946: Public Health Reports, v. 61 , no. 11, p. 371-384.

Wetzel, W. W., and McMurry, H. V., 1937, A set of type curves to assist in the interpretation of the three-layer resistivity problem: Geophysics, v. 2, no. 4, p. 329-341.

Wilcox, L. V., 1948, The quality of water for irrigation use: U. S. Dept. Agriculture Tech. Bull. $962,40 \mathrm{p}$. 


\section{INDEX}

Acknowledgments $\quad$ Page

Agriculture........................................295

Alamo, gaging station............. 295, 314, 315 location..................................292

Alluvium, composition....................299, 303 occurrence of ground water............307-308 thickness....................299, 301, 302, 303 volume......................................308

Artillery formation.......................300, 302

Big Sandy River................................292

Bill Williams River, description..............297 discharge.........................306, 307, 314 drainage area..................................293

location.....................................292

surface flow...........................305-306, 307

temperature of water....................... 305

underflow...............................307, 309

Buckskin Mountains......................297, 298

Bullard Wash............................. 297, 298

Chapin Wash formation....................300, 302

Clays, lake-bed............................298, 299

Climate...................................292-295

Congress Junction...............................292

Date Creek...........................297, 298, 299

Drainage..........................................297

Electrical-resistivity surveys.............303-305

Erosion.....................................298, 308

Evaporation....................................... 311

Faulting..................................298, 302

Field work............................295-296

Folding...........................................302

Formations.............................299, 300

Gaging stations.....................295, 305, 307

Geophysical studies.................. 295, 303-305

Ground water, downstream from

Alamo...........................317-318

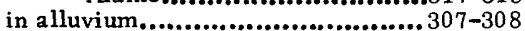

kinds of discharge............................ 309

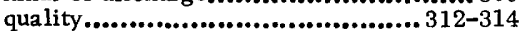

recharge....................................308

Page

History of development.......................295

Infiltration gallery.............................316

Irrigation, recharge by....................... 309

Lava flows................................. 298

Manganese deposits, investigations.........292

water needs for mining......... 292, 314-315

Mining....................................292, 295

Phreatophytes............................311, 316

Planet gaging station....................295, 307

Precipitation....................293, 308-309, 315

Pumpage.................................... 311

Quaternary formations..................298, 300

Salome............................292, 293, 315

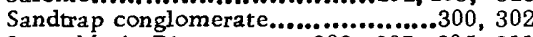

Santa Maria River...........292, 297, 305,311

Spring records...................................310

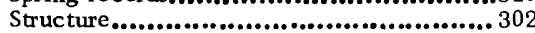

Surface water, measurements........ 305-307,

......................... 312-314

site for reservoir.............................317

Temperature of river water...................305

Tertiary formations................. 297-298, 300

Test holes........................................302

Topography..............................297, 298

Transpiration...........................311, 316

Underflow, interception......................316

volume ........................................ 311

Water supply, development.............314-318

Wells, drilling.................................316

numbering system............................296

pumpage.................................. 311

records.........................................310

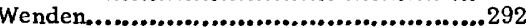

Yucca............................................292

\U. S. GOVERNMENT PRINTING OFFICE : 1956 O - 396664 